\title{
Peculiar Characteristics of (Vietnamese) Painting Language: Oil Painting and Contributions From Notable Painters Including Le Van Mien, Thang Tran Phenh and Nam Son
}

\author{
Nguyen Van Doan (Wentuan Ruan) \\ School of Art Hunan Normal University, Hunan, China \\ Ho Chi Minh City University of Fine Arts, Ho Chi Minh City, Vietnam
}

\begin{abstract}
This paper summarizes the painting artistry from three painters: Le Van Mien, Nam Son, and Thang Tran Phenh with the following notable characteristics: realism, impressionism, and contemporary humanism. It is visible from their works that these three artists have managed to define their ways to create arts reflecting the Vietnamese people in the period of transition between 19th and 20th Century Vietnam. Contemporary humanism has always been a great aspiration to any painter in any time period. During the life and work of painters, it is the visible themes of human beings in their work that best reflect how the artists perceive life. While considered to be the pioneering figures in Vietnamese oil painting registry of art, the three painters Le Van Mien, Nam Son, and Thang Tran Phenh all happened to favor the humanism theme in their oil painting works. There were two most commonly accepted explanations for this choice. First of all, most artistic geometry lessons for beginners often choose the human figure to be the starting model for study and creative development. Secondly, during the trans-century period when Eastern and Western cultures collided in Vietnam during the late 19th early 20th Century, humans and most notably the Confucianists were the most vivid storytellers of the day and age.
\end{abstract}

Keywords: Le Van Mien, Nam Son, Thang Tran Phenh, oil painting

\section{Oil Painting Characteristics From the Three Pioneer Artists}

\section{The Human Character}

The thematic choice of humanism usually meets the creative tendencies in geometric creativity and being reflective of the then-modernist spirit. There was a common question however, about why different themes such as landscape, still life, or expressionism were not favored by the pioneer oil painters. In essence, before Le Van Mien, Nam Son, and Thang Tran Phenh, the Vietnamese painting community has not acquired a defined "voice", or expressive signature that could stand as normative guidance for different methods of artistic expressions being experimented at the time. The Vietnamese people in general were mostly used to only the limited collection of the commonly recorded forms of artistic paintings native to Vietnam and uniquely labeled in style as Hang Trong, Dong Ho, Hoang Mai, Sinh Village, or ancestry shrine tribute paintings (which were often found in more isolated indigenous municipalities). If there were any direct contact with "mainstream" art

Van-Doan Nguyen (Wentuan Ruan), Doctoral Student, School of Art Hunan Normal University, Hunan, China; Ho Chi Minh City University of Fine Arts, Ho Chi Minh City, Vietnam. 
culture at the time, it would be spotted mostly as decorative features on enameled pottery or crafts, which were subconsciously distanced from painting definitions. In creative geometry, the traditional estimative techniques in size and shape were used for most landscape contents including the human figures, with mostly popularized topics portrayed with pre-existing stories and structures. Such way of painting had been passed down from generation to generation. The depiction of the characters in shape, form, and suggestive movements are the key leads for appraisers to acquire the meanings from the collective "ancient creators" of this traditional style of painting. Most notably, the human faces in these ancient works of art were largely similar in expressions. It could be postulated that these dated norms and rigid methodology made up the reason behind painters such as Le Van Mien, Nam Son, and Thang Tran Phenh to select the humanistic topics of choice in their ventures for new, more creative expressions in oil colors.
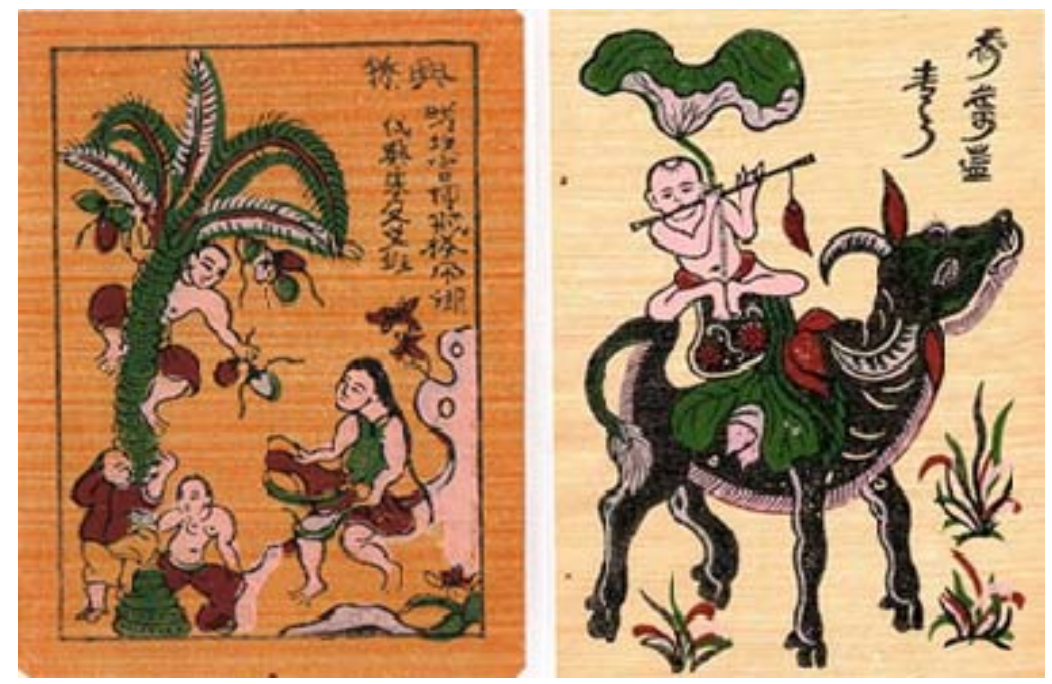

Figure 1. Dong Ho traditional painting: "Harvesting Coconuts”, "Pasture Boy Playing the Flute”.

In realism painting, this move was considered to be the deviation from traditional concepts of fine art in Vietnam, particularly in oil painting. Prior to this transition, the creative works in traditional arts such as municipal shrine sculpture and popular paintings all made use of the estimations from memorized figures with basic lines, simplified coloring meant for more illustrative depiction rather than exploring the depths of the characters. Also, the learning of the art was not pedagogically structured, but passed down from generation to generation of the then-considered "crafty" individuals. Realism in painting incorporated many different styles, as it represents the basic lessons for many beginners in the way of the painting arts. Thus, it is not difficult to spot traits of Realism in the works of Le Van Mien, Nam Son, and Thang Tran Phenh. Besides, the artistic training environment was critical factor shared by the early Realism creations of all three pioneer painters as they started practicing with the oil format.

It is relatively easy to spot the differences in geometric artistry between the three painters. Appraisers could make out the intricacy in minute details from the paintings of Le Van Mien and Nam Son, but the same traits were not identified in the works of Thang Tran Phenh. These showed the differences from the classical training that Le Van Mien and Nam Son enjoyed during their time in France, and the limited contact with classical themes and methodology by Thang Tran Phenh through the word-of-mouth descriptions relayed to him in Vietnam by his travelling friend. 
Realism painting in the creations of these three artists was not limited to the relatively more accurate depiction of the character and thematic models, but also attentive to the expressions and individualistic contents contained in the models. In the oil paintings of Le van Mien, notably his "Elderly Tutor Men", and "Literature Appreciation”, the appraisers could visibly absorb better the Realism of the day age. In "Elderly Tutor Men”, the sitting posture and face of the main character all depicted the expression, the style and stereotypical traits of a Confucian scholar. The reality portrayed in such character was not limited to expressive attires and posture. The tutor was depicted with a stern look, definitive eyes, straight nose and silver-greyed long beard most stereotypically associated with Confucian scholars of the time. In "Literature Appreciation", painter Le Van Mien again showed the appraisers of his work the combination of realism depiction in his point of view, positioning of the characters and the perspectives he formed. The painting not only included multiple unique characters, but also the details suggesting realistic state of mind and intention in every single character. Each character seemed to have "fulfilled" their part in the story told by the painting, as if in the eyes of Le Van Mien such portrayal was sufficient in itself and his job was merely to fill in the realistic details until perfection.

The painting "North country Confucian” by Nam Son also carried the full, similar language of Realism. In the completion of this painting, Nam Son had to carefully study the character's stereotypes in an expected working environment. Such preparation could be seen through the stern portrayal of the brows, to the hand with long fingernails stereotypically associated with Confucians in the time period of late 19th to early 20th Century Vietnam. Compared to the predecessor painters, Thang Tran Phenh seemed somewhat lacking in his realistic recreation of the characters. This can be categorically accepted as a simple lack of contact with classical school of art previously noted. His work made use of realistic geometry formation, but only to a limited effort. In particular, his approach could be seen in the painting "Laotian Woman": details in the forehead, eyes, the foldings in the scarf and tunic, have shown initial realism influences in yet unsubstantial geometric formation and less critical execution. The general conclusion from the initial work with the oil medium, these three painters showed their access to Realism paintings as a self-defined salvation and the rebellious creativity not previously seen in traditional artistic paintings of Vietnam.

\section{Impressionist Coloring With Strong Personality Portrayal}

The colors peculiar to Impressionism are the result of liberal mixing of the defined color gammas together for the purpose of highlighting the details in the transition zones and light in the painting. This approach can be clearly seen from the works of painter Nam Son. The only oil medium example in his work that was well-preserved to this day is the "North country Confucian" that most definitively showcased the lighting and coloring of the Impressionism philosophy. As mentioned previously, Nam Son paid critical attention to the quality and dynamic transition of light in his work. Thanks to the characters of the oil medium, the appraisers could readily perceive the "paths" of light in the scene portrayed by the painting. As perception of light is the key to the Impressionist school of artistic painting, during his years studying fine arts in France Nam Son has mastered the techniques and philosophy of the Impressionism discipline and applied it to all media that he worked with. The painting "Riverside Rice Market” (1930) in black-and-white Confucian ink presented a solid proof of his disciplines. 


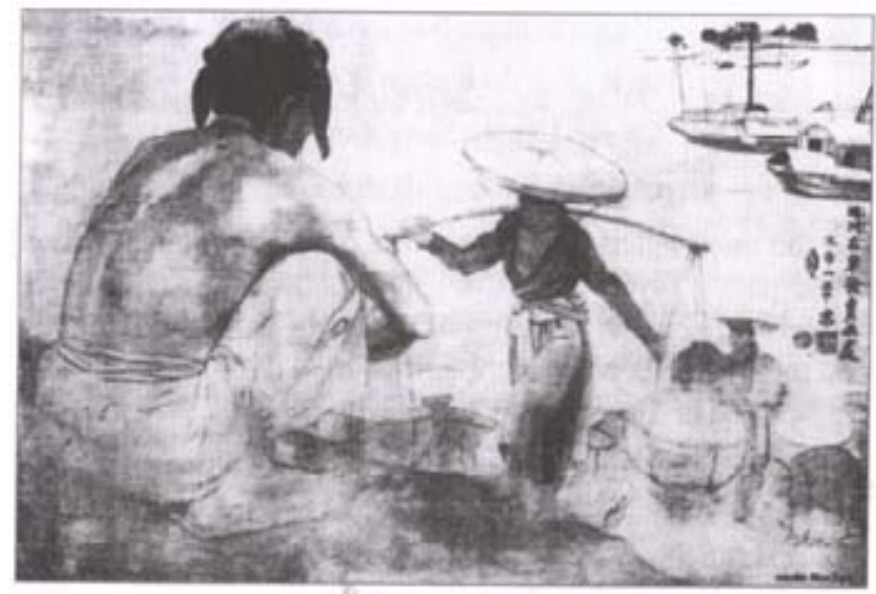

Figure 2. Nam Son, “Riverside Rice Market”, black-and-white Confucian ink, 1930.

Nam Son tried his best to fully utilize the European style of Realism portraiture, showed his obsession with storied details and the depiction of light, the geometric formation and execution of color blending that were all too distant from the traditional Vietnamese paintings. The painting "Riverside Rice Market" (see Figure 2) was the voice of Nam Son in his artistic expression. In only two shades of black and white, appraisers could already perceive the sunlight reflecting off the human figures and smearing onto the view of a sun-washed river. The seemingly rushed black lines actually showed careful contemplation that complemented the intricacy of the painting as a whole, a stark difference from the Water Ink style of Chinese-origin often associated with Confucian ink paintings.

The three painters Le Van Mien, Nam Son, and Thang Tran Phenh have crafted their own pioneering steps into a fully developed painting art through three key factors: the human figure, Realism painting, and Impressionist painting. Although many works from these painters did not completely incorporate all these factors on the same canvas, appraisers could already feel the efforts shown by the painters during their time period filled with traditional crafts and influx of international classical values.

\section{Contributions by the Three Painters Le Van Mien, Nam Son, and Thang Tran Phenh to the Development of Vietnamese Oil Painting}

Previous analysis shows that, while Vietnamese oil painting had begun its initial steps, during the times of the three pioneer painters the art was not completely ready for an East-and-West merge. For the vast majority of scholars, artists and people at the time, Western paintings were of alien quality and values and not yet perceived as a new school of art. The initial contributions from Le Van Mien, Nam Son, and Thang Tran Phenh were considered to be the critical buffer that marked the introduction of Vietnamese-crafted oil paintings to the Vietnamese painting profession. Such contribution can be categorized into three separate key values: artistic pursuit, historic contribution, and an oil painting milestone for Vietnamese painting registry.

\section{Artistic Pursuit}

This may be the prerequisite for the creative drive from the three pioneer artists as the first Vietnamese to pursue the profession and art of the oil medium. Right from their first days in France in different circumstances, both Le Van Mien and Nam Son chose to pursue fine arts as their major and developed themselves into independent-minded painters. The case of Thang Tran Phenh as a painter that sought to develop his arts via the 
ideals transcribed through the descriptive words of a friend, also made the same case of the independent pursuit in art. In their transitioning period where the traditional crafts had impregnated so deep a discipline into the Vietnamese appraisal of the fine arts, the will to follow through with dreams and independent thoughts were the common denominator in otherwise completely three different fates. Le Van Mien went to France through scholarly pursuit bestowed for the privileged Vietnamese aristocracy. He was initially completely indifferent to the art of painting and focused his attention to the study of politics. Only after his primary and intended education, had Le Van Mien discovered his enjoyment and love for fine arts. Nam Son originated as a Confucian scholar well versed in the modern knowledge of the time. He eventually realized the fading of Confucianist ideals in his day and age, the portrayal of which was hinted in his painting "North country Confucian”. It was not a rare or new occurrence where inspiration of life and society influenced artistic creation, as Nam Son attempted to depict and voice his concerns through the character in his painting, which is a rigid scholar dedicated to his school of philosophy and realized how powerless he was before the shifting culture of the age and the incompatibility of his ideals. In the painting "Pham Ngu Lao" by Thang Tran Phenh-the oil painting that was considered the Vietnamese first in the historical portrayal, the choice of format and expression methodology specific to the oil medium showed a completely new approach in the historical portray category seen in Vietnam thus far. It was from that point that successor painters attempted to explore, create and expand the art focused on historical topics in multiple formats and media. In summary, the creations of the three painters Le Van Mien, Nam Son, and Thang Tran Phenh affirmed the artistic pursuit that forebears all breakthrough and discovery of the painting art.

\section{Cultural Values}

Through the figurative formation by Nam Son, the image of a Northcountry Confucian highlighted the eyes that seem to question the survival of Confucius's values and integrity in the coming day and age. Such questioning eyes showed both confusion and aversion to the drastic changes of his country and culture. The normative figures of Confucian scholars in the works of Le Van Mien all shared a familiar spirit. In the depiction of formal scholarly attires, the oil paintings of Le Van Mien and Nam Son, or the traditional attire of a Laotian Woman by Thang Tran Phenh all showed a clear and definitive regional and/or cultural identification. The human figure formation in the works of these three artists showed appraisers their views on the late 19th and early 20th century Vietnamese culture. Even the theme and story associated with these human portrayals presented a unique take on the oil medium exploration in its beginning in Vietnam.

The oil painting "Literature Appreciation" by Le Van Mien showed appraisers the Vietnamese culture frequented by the Confucian scholars, their students and their peers. Those who are familiar with the Vietnamese literature most popular at that period of time could readily perceive appreciation of works such as “Tale of Kieu”, "Lament of a soldier’s wife”, “The Summa Cum Laude Quynh”, among various others. Appreciation of fine literature is a special cultural activity that deeply associated and integrated with social interactions in Vietnam up until that time period, if not still in effect to the modern day. Painter Le Van Mien seemed reminiscent of what was popular in the traditional art he inherited. This nostalgic behavior did not seem to ever surface again throughout the warring periods in Vietnam during the many decades afterwards and arguably still not even seen in today's efforts of heritage restoration. In comparison to many contemporary fine arts at the time, notably the mass-printable painting "Encyclopedia of tools, utensils and behavior in the profession of Northcountry Vietnamese", or alternatively known simply as "Vietnamese Crafts" by painter 
Trong Hai under the commission of research Henry Oger (see Figure 3). This wooden print negative had an almost complete picture of culture, beliefs, traditions of Vietnam crafted into its presentation via painting language developed by Vietnamese painters, pioneers and those afterwards included.

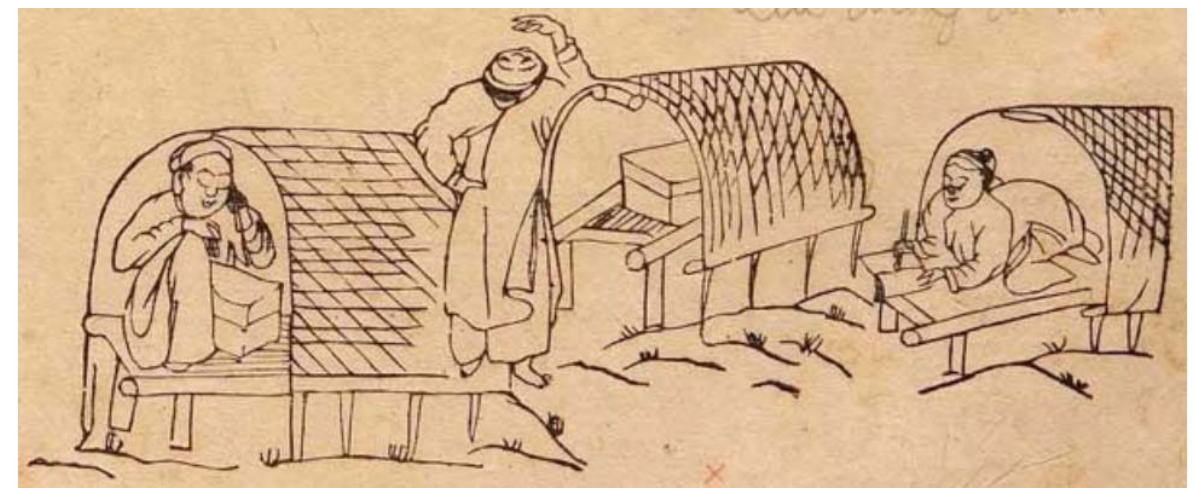

Figure 3. Henri Oger, “Examination pods” (from “Vietnamese Crafts”), printed from sculpted wooden negative, 1908.

Nevertheless, the oil painting works by the three pioneer painters were generally differently appraised. The early oil paintings were mostly confined in topics of humanism, but under the influence of Realism and the Impressionist coloring techniques the three pioneer painters have managed to bring about the most realistic portrayal of the human of Vietnam during their time period. This portrayal in its complete presentation is starkly different from the presentation shown in the restoration/preservation-purposed, renaissance-themed "Vietnamese Crafts". It could be viewed in the facet of contemporary culture (at the time), the coloring and figurative formation originated from Western schools of fine arts made their ways into the oil paintings of Le Van Mien, Nam Son, and Thang Tran Phenh, then eventually were incorporated into the expressive colors and portrayals of cultural themed creations in later Vietnamese arts and crafts.

\section{Conclusion}

Before the advent of Le Van Mien, Nam Son, and Thang Tran Phenh, Vietnamese painting in general, or Vietnamese oil painting in particular had not possessed a consistent language of expression. Most artistic activities and creations were often associated with decorations affixed to other craft forms such as ceramics or wooden structures/sculptures. There was no uniquely identified painting foundation as seen in various other East Asian cultures (Mainland China, Japan, or Korea). The inconsistency and lack of active discovery were to blame for the long hiatus of creative painting, which eventually ended by the advent of the three pioneers Le Van Mien, Nam Son, and Thang Tran Phenh. The first steps of these three artists, albeit slow and somewhat struggling, were the definite contribution to a more developed future of Vietnamese painting profession and its schools of art. Le Van Mien, Nam Son, and Thang Tran Phenh made use of their absorption of Western techniques and classical ideals to broaden their native, traditional disciplines in Vietnamese craft culture and managed to create transitional works that transcend different cultures and artistic systems. With their deep roots in the village-born municipality culture, Le Van Mien, Nam Son, and Thang Tran Phenh were fundamentally inspired by the ancient arts circulating the Vietnamese community in their time. Le Van Mien's oil coloring was the most vivid proof for the traditional appreciation of the earthen colors as well as the techniques in Western classical painting for transitioning of light zones. Le Van Mien's “Tutor Men” showcased the Impressionist minimal formations of a neutral greyish purple background to the loosely fitted tunic of the 
character model, overall saturated by the reddish brown shade reminiscent of the traditional lacquered paintings and sculptures of old. These lingering traits of the traditional crafts may show a reason behind a slow start for the merging of Western and East Asian cultures in artistic painting expressions. However, particularly in the painting profession, the oil medium works by Le Van Mien, Nam Son, and Thang Tran Phenh contributed a fundamental transition buffer for the Vietnamese painting scene and marked its history of development after a long period of satisfaction with traditional arts of ancient origin. From these pioneer works, appraisers could completely place their reference point into the milestone that marked the beginning of a new future for Vietnamese painting since modernization, which has been further enriching Vietnamese culture in the process.

It is from this point that Vietnamese painting started defining its place in the global map of fine arts with compatible and comparable systems of values, created by independent, individually recognized artists (in opposed to the pre-existing traditional Vietnamese crafts that never named an original creator). Creating original work of art while also maintaining traditional values of the Vietnamese crafts appeared to be the main "conversation" between contemporary artists (at the time) and their traditions. Utilizing Western techniques to form their own individualistic expressions in the Indochina collective culture of anonymous crafts has been witnessed time and again, through actual painting works, to be the legacy of the pioneer artists.

\section{References}

Cao, T. T. (2011). Vietnamese fine art in 20th century from the perspective of Vietnamese fine arts museum. 45 years of Vietnamese Fine Art Museum Memorabilia, 28-31.

Nguyen, Q. (2010). Vietnamese fine art in 20th century. Hanoi: Knowledge \& Wisdom Publishing.

Nguyen, T. C. (2008). Vietnamese history of fine arts. (Vietnamese) National University of Education Publishing, 170-172.

Pham, L. (2010). Postmodernism: The unsolvable cultural crisis. Vietnam National Front, Central Committee, 211, 40-43.

Philip, M. (1999). Introductory note. In ASEAN Arts in the Onset of the 21st Century. Philip Morris's 1999 ASEAN Fine Art Exhibition.

Thai, H. C. (2011). Vietnam’s “National Painting” in Uyghur, China. (Vietnamese) Fine Arts \& Photography, 4 (Special Issue), 6-7.

Tran, K. C. (2012). 20th Century Hanoi’s fine arts. Hanoi: Fine Art Publishing.

Tran, V. B. (2001). Vietnamese culture in international economic integration. (Vietnamese) Cultural Heritage Magazine, 3(28), 23-24.

Vietnamese Fine Art Museum Memorabilia. (1996). 30 years of Vietnamese Fine Art Museum, 1966-1996.

Vietnamese Fine Art Museum Memorabilia. (2011). 45 years of Vietnamese Fine Art Museum, 1966-2011. 